\title{
Dijagnostika î kirurško liječenje medijalnog iščašenja ivera u pasa
}

\author{
Marko Pećin*, Anja Samardžić, Ozren Smolec i Mario Kreszinger
}

\section{Sažetak}

Medijalno iščašenje ivera česta je pojava i uzrok šepanja $u$ malih pasmina pasa te ima veliko značenje u veterinarskoj praksi. Međutim, kirurško liječenje lakših slučajeva, osobito I stupnja često se izbjegava i ne smatra bitnim. Konzervativno liječenje ne daje zadovoljavajuće rezultate. Iščašenje može nastati zbog traume, ali može biti prisutno već pri rođenju što je često povezano $\mathrm{s}$ težim deformacijama kostiju. Nasljednog je karaktera. Težina kliničkih znakova ovisi o stupnju iščašenja ivera, a u nekim slučajevima kada nema kliničkih znakova do dijagnoze se dolazi tijekom rutinskog kliničkog pregleda. Osim ortopedskog pregleda, dijagnoza se postavlja na temelju rendgenskog snimanja koje može biti negativno u I ili čak II stupnju iščašenja. Vrsta operativnog zahvata ovisi o stupnju iščašenja, a može se temeljiti na rekonstrukciji mekih tkiva ili kostiju. Najčešće korištene tehnike su zatezanje lateralnog retinakuluma $\mathrm{s}$ otpuštanjem medijalnog retinakuluma, produbljivanje trohlearnog kanala, odnosno trohleoplastike i premještanja goljenične kvrge lateralno i čak blago distalno. Kod težih deformacija kostiju primjenjuje se korektivna osteotomija bedrene kosti. Danas postoje i moderne metode liječenja ovog ortopedskog problema kao što je korištenje implantanata ili endoproteza koje povećavaju ili u potpunosti zamjenjuju trohlearni žlijeb. Ove tehnike imaju znatno višu cijenu. Veliku ulogu u liječenju treba dati i postoperativnoj analgeziji te imobilizaciji noge. Rjeđe se događaju veće komplikacije, ali se može javiti ponovno iščašenje ivera, popuštanje implantanata što se smatra najčešćim te lom goljeničke kvrge kao najteža komplikacija. U većini slučajeva prognoza je odlična, noga se vraća normalnoj funkciji, a hromost se ne pojavljuje. Ovaj rad ukratko opisuje kliničku sliku, dijagnostičke metode i kirurško liječenje medijalnog iščašenja ivera u pasa uz osvrt na suvremene kirurške metode.

Ključne riječi: iver, iščašenje, stupanj iščašenja, kirurško liječenje, implantati

\section{Uvod}

Medijalno iščašenje ivera predstavlja jedan od najčešćih ortopedskih problema koljenskog zgloba (Roush, 1993.). Kod ovog stanja dolazi do izlaženja

ivera iz njegovog prirodnog položaja unutar hrskavičnog žlijeba valjka bedrene kosti. Ono ponajprije zahvaća male i minijaturne pasmine pasa, ali

Dr. sc. Marko PEĆIN*, dr. med. vet., docent, (dopisni autor, e-mail: mpecin@vef.hr), Veterinarski fakultet Sveučilišta u Zagrebu, Hrvatska; Anja SAMARDŽIĆ, dr. med. vet., Hrvatska; dr. sc. Ozren SMOLEC, dr. med. vet., izvanredni profesor, dr. sc. Mario KRESZINGER, dr. med. vet., redoviti profesor, Veterinarski fakultet Sveučilišta u Zagrebu, Hrvatska 
se povećava i broj slučajeva u mladih pasa velikih pasmina (L'Eplattenier i Montavon, 2002.). Većinom je medijalno iščašenje ivera kongenitalno stanje i sigurno je nasljedno, iako nije opisan način nasljeđivanja. Česti su traumatski slučajevi kada su pogođene retinakularne strukture, naročito s bočne strane (Denny and Butterworth, 2000.).

Razvijen je sustav ocjenjivanja koji je utemeljen na nalazu pri kliničkom pregledu i rendgenskim snimkama te se prema tome težina medijalnog iščašenja ivera svrstava u četiri stupnja. Psi s prvim stupnjem iščašenja često ne pokazuju nikakve kliničke znakove dok se u pasa $\mathrm{s}$ trećim ili četvrtim stupnjem javlja šepavost, bolnost i životinja rasterećuje nogu.

Općenito, prvi stupanj nije potrebno kirurški liječiti, dok se ostali stupnjevi redovito podvrgavaju kirurškom liječenju. Iščašenja ivera višeg stupnja je teže popraviti i vjerojatnije je da će se ponoviti. Glavni ciljevi kirurškog liječenja su usklađivanje ekstenzornog mehanizma, produbljivanje hrskavičnog žlijeba bedrene kosti, zatezanje mekih tkiva lateralno od ivera i smanjenje napetosti mekih tkiva medijalno od ivera.

Na ovim se načelima temelji kirurško liječenje medijalnog iščašenja ivera pa $s$ obzirom na to postoji i više vrsta operativnih zahvata kojima se ovo stanje liječi. U današnje vrijeme razvijene su i neke suvremene metode koje sve više pronalaze primjenu $\mathrm{u}$ veterinarskoj medicini. S obzirom na učestalost ovog ortopedskog problema rad opisuje etiologiju, dijagnostiku i načine liječenja medijalnog iščašenja ivera $u$ pasa.

\section{Iščašenje ivera}

Iščašenje ivera nastaje kod razmicanja zglobnih ploha i izlaženja ivera iz njegovog prirodnog položaja. Iver se nalazi u hrskavičnom žlijebu bedrene kosti po kojem kliže uklopljen u tetivu $m$. quadriceps femoris i zajedno čine "ekstenzorni mehanizam". Kada se mišić kontrahira, on privlači tetivu i iver čime dolazi do ekstenzije. Iščašenje ivera je stanje u kojem iver iskoči iz hrskavičnog žlijeba tijekom fleksije koljena. Ovisno o tome radi li se o unutarnjoj ili vanjskoj strani koljenskog zgloba govori se o medijalnom ili lateralnom iščašenju.

Medijalno iščašenje ivera zahvaća najčešće male pasmine pasa kao što su: Boston i Yorkshire terijeri, čivave i minijaturne pudle. Pojavnost $u$ velikih pasmina pasa je u posljednje vrijeme $\mathrm{u}$ porastu, a pasmine kao što su Shar Pei, labrador retriver i Akita smatraju se predisponiranima. U $75 \%$ do $80 \%$ slučajeva medijalno iščašenje je češće od lateralnog, dok u malih pasmina pasa učestalost dostiže i do $98 \%$ (Campbell i sur., 2010.). Iščašenje može biti unilateralno, a u polovici svih slučajeva zahvaća i drugo koljeno što dovodi do nelagode, bolnosti i gubitka funkcije. Što se tiče spolne predispozicije medijalno iščašenje češće zahvaća ženke malih pasmina te mužjake velikih i gigantskih pasmina.

Uzroci koji dovode do medijalnog iščašenja ivera mogu biti kongenitalni, genetski i traumatski. Međutim, u većini slučajeva uzrok nije $u$ potpunosti razjašnjen i smatra se da u nastanku sudjeluje više faktora. Hrskavični žlijeb bedrene kosti po kojem klizi iver može biti plitak, a može i nedostajati $\mathrm{u}$ pasa $\mathrm{s}$ netraumatskim iščašenjem. Rana dijagnoza obostranog iščašenja uz odsustvo traume podržava teoriju kongenitalnog i iščašenja zbog razvojne neusklađenosti ekstenzornog mehanizma. Ono se više ne smatra kao bolest sama po sebi već je posljedica složenih skeletnih abnormalnosti koje zahvaćaju cijeli ud, a to mogu biti abnormalan oblik kuka (kao što je displazija kuka), nepravilna bedrena kost s poremećenim kutevima u odnosu 
na goljeničnu kost i torzija bedrene kosti, nepravilnosti goljenične kosti, nepravilnost goljenične kvrge na koju se veže tetiva s uklopljenim iverom, krutost ili atrofija $m$. quadriceps femoris (djeluje kao luk) i predug patelarni ligament. Budući da postoje dokazi da je ovo stanje barem djelomično genetski uvjetovano, psi s dijagnozom iščašenja ivera ne bi se smjeli koristiti za rasplod.

\section{Klinička slika}

Klinička slika medijalnog iščašenja ivera varira ovisno o težini stanja. Ovo stanje može biti sasvim slučajan nalaz pri rutinskom pregledu, ali može biti i ozbiljnije u vidu držanja uda u zraku i neoslanjanja. Većina pasa koji su zahvaćeni tom bolesti iznenada počnu držati nogu u zraku ili za nekoliko koraka "preskočiti", a može se vidjeti potresanje ili ispružanje noge prije sljedećeg koraka. Kako bolest napreduje u trajanju i težini, hromost biva češća i izraženija dok na kraju ne postane kontinuirana. Bolest će se manifestirati različito ovisno o stupnju iščašenja. Prvi stupanj obično je slučajan nalaz. Iver se lako može manualno iščašiti, ali se vraća u početni položaj odmah nakon puštanja. Nije prisutna krepitacija tijekom pasivnih kretnji zgloba niti je primjetna deformacija kosti te obično nema kliničkih znakova. Drugi stupanj karakterizira spontano iščašenje uz hromost koja je bezbolna i nalikuje "preskakivanju". Razvijaju se blage deformacije $\mathrm{u}$ obliku unutarnje rotacije goljenične kosti te abdukcije kuka. Postoji mogućnost da napreduje u treći stupanj uz progresivnu eroziju hrskavice zglobnih površina ili dovede do puknuća prednjih križnih ligamenata. Treći stupanj je karakteriziran stalnim iščašenjem ivera koji se manualno može vratiti u prirodni položaj. Dolazi do težih deformacija kosti kao što je znatna rotacija goljenične kosti te iskrivljenost distalnog dijela bedrene kosti i proksimalnog dijela goljenične kosti. Plitak hrskavični žlijeb moguće je opipati dok je iver iščašen, a hromost je u korelaciji s opsegom erozija hrskavice. Često se manifestira kao nenormalan hod i stav kao da životinja "čuči". Najčešće se javlja bilateralno. Četvrti i najteži stupanj je trajno iščašenje ivera bez mogućnosti vraćanja u prirodni položaj. Korekcija bi trebala biti učinjena u ranoj fazi života zbog toga što dolazi do težih deformacija kostiju i ligamenata, a daljnjim razvojem kirurška obrada postaje zahtjevnija. Teške koštane deformacije karakterizirane su rotacijom goljenične kosti za 60 do 90 stupnjeva u odnosu na sagitalnu ravninu. Stupnjevi medijalnog iščašenja prikazani su na slici 1.

\section{Dijagnostika}

Za postavljanje dijagnoze potreban je oprezan i temeljit klinički, odnosno ortopedski pregled kako bi se opisao stupanj iščašenja ivera i istodobno isključilo puknuće prednjih križnih ligamenata te drugih patologija koje su mogle dovesti do hromosti stražnjih nogu. Pregled se izvršava i dok životinja hoda kako bi se uočile druge deformacije te stupanj hromosti. Postoji nekoliko čimbenika koji se treba uzeti u obzir prilikom izrade plana liječenja kao što su: nestabilnost koljena, položaj ivera,

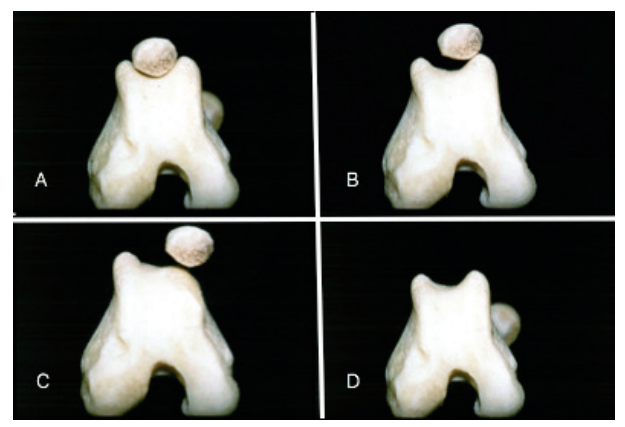

Slika 1. Prikaz stupnjeva medijalnog iščašenja ivera. S lijeva na desno; A -I stupanj, B-II stupanj, C-III stupanj i D- IV stupanj medijalnog iščašenja ivera. Izvor: http://cal.vet.upenn.edu/projects/ orthopod/oldsite/mpl/mpl04.htm 

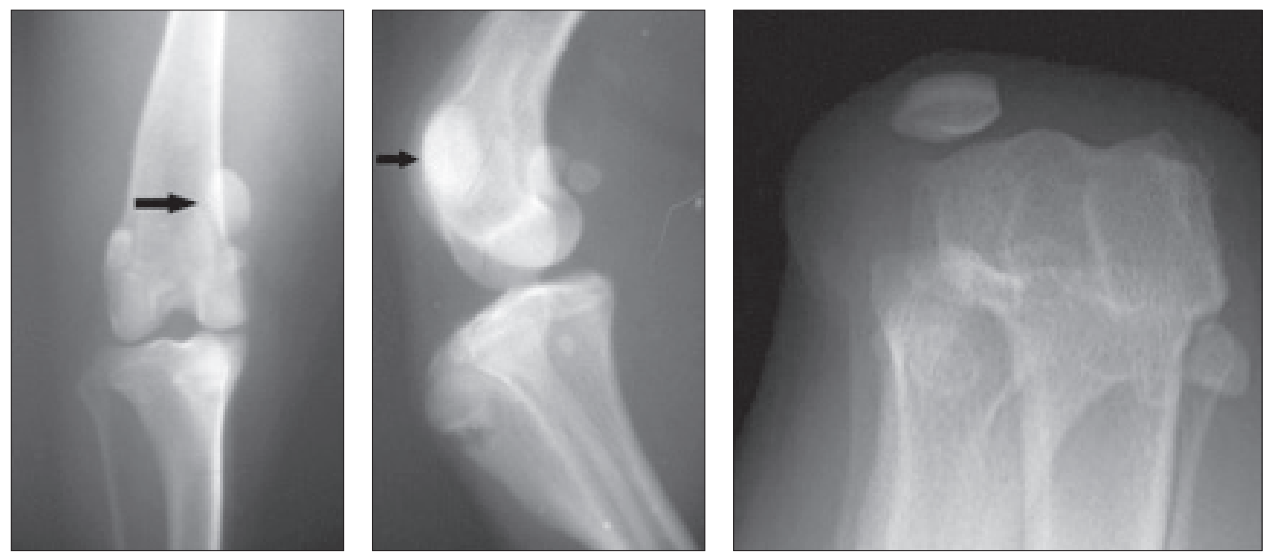

Slika 2. Rendgenski prikaz medijalnog iščašenja ivera s lijeva na desno; u sagitalnoj, profilnoj te "skyline" projekciji

mogućnost ili nemogućnost manualnog vraćanja ivera u prirodni položaj, prisutnost ili odsutnost krepitacije, stupanj devijacije goljenične kvrge, torzija uda, opseg kretnji te pozitivan ili negativan test ladice. Početni pregled se provodi na pacijentu koji stoji tako da je stav obje noge simetričan te da se pri kontrakciji m. quadricepsa femoris može procijeniti stabilnost ivera i postojanje otečenja ili izljeva u zglob. U slučaju kada je zglob dosta upaljen lociranje ivera može biti otežano, ali se tada može pratiti patelarni ligament od njegovog hvatišta na goljeničnoj kvrgi. Iver se izolira između palca i kažiprsta jedne ruke, dok se drugom rukom drži za goljeničnu kost te podiže tarzus od podloge. Provodi se fleksija, ekstenzija i rotacija koljena, a istodobno manualno izvršava pritisak prstima medijalno, odnosno lateralno kako bi se procijenio smjer i stupanj iščašenja ivera. Ponekad napetost mišića sprječava iščašenje pa se stoga pregled provodi tako da pas leži u bočnom položaju. Dubinu hrskavičnog žlijeba potrebno je procijeniti dok je iver izvan prirodnog položaja. Usklađenost mehanizma $m$. quadricepsa femoris procjenjuje se na životinji koja leži na leđima tako da se prati usklađenost $m$. quadricepsa femoris, ivera, patelarnog ligamenta i goljenične kvrge dok su kuk, koljeno i tarzus u ekstenziji. Ako je životinja nemirna primjenjuje se sedacija kako bi se mogao dovršiti ortopedski pregled i rendgensko snimanje udova. Rendgenske snimke su od velike pomoći pri određivanju stupnja iščašenja i uočavanju degenerativnih promjena u zglobu, odnosno koštanih deformacija. Rendgenske snimke se najčešće rade u ventro-dorzalnoj projekciji pri čemu su obje stražnje noge ekstendirane. Poželjno bi bilo slikati i u latero-lateralnoj projekciji kako se sa sigurnošću mogu ustvrditi ili isključiti deformacije kostiju i drugi patološki procesi. Postoji i „skyline“ projekcija gdje je koljeno snimljeno iz kranijalnog kuta čime se vidi dubina žlijeba trohleje i položaj patele u fleksiji (Slika 2.).

\section{Liječenje}

Liječenje iščašenja ivera može biti konzervativno i kirurški. U većini slučajeva ipak će prevladati kirurške metode liječenja. Konzervativan način liječenja (simptomatsko i potporno liječenje), uključujući i rehabilitaciju, može se primijeniti kod prvog stupnja iščašenja 
gdje nema izraženih kliničkih znakova kako bi se poboljšao mehanizam $m$. quadricepsa femoris. S druge strane, kod trećeg ili četvrtog stupnja iščašenja kirurško liječenje u ranoj fazi je neizbježno. U složenijim slučajevima nekad nije lako izabrati način liječenja. Kirurško liječenje je indicirano ako se javi značajna hromost u posljednjih dva do tri tjedna ili duže ili se javlja više uzastopnih epizoda hromosti u kratkom vremenskom razdoblju te se nestabilnost koljena pogoršava. U slučajevima kada su epizode hromosti blage i neredovite, a stupanj osteoartritisa blag, može biti indicirana konzervativna metoda liječenja uz praćenje ozbiljnosti i frekvencije pojave hromosti. S druge strane, novija studija Rezende i sur. (2016.) kaže da iščašenje ivera treba podvrći kirurškom zahvatu čak i kada su klinički znaci bolesti blagi ili odsutni (prvi i drugi stupanj), jer ovo stanje prouzroči promjene na iveru i koljenskom zglobu koje mogu rezultirati težom operacijom i potiču napredovanje degeneracije zglobova čime se smanjuje vjerojatnost potpunog oporavka funkcije zglobova. U vrlo mladih pacijenata, koji još uvijek rastu, izbjegava se kirurško liječenje u smislu tehnika rekonstrukcije kosti zbog kojih bi moglo doći do ozljede bedrene i goljenične fize te posljedično prestanka rasta kosti. U težim slučajevima u obzir se uzima liječenje u dva stadija od čega prvi podrazumijeva rekonstrukciju mekih tkiva, a nakon dostizanja zrelosti kostura primjena metoda rekonstrukcije kosti. Iako, najnovija studija Gallegos i sur. (2016.) sugerira provođenje jednog operativnog zahvata s korištenjem kombinacije više tehnika odjednom posebice kod obostranog iščašenja ivera.

Glavni ciljevi kirurškog liječenja medijalnog iščašenja ivera su: uskladiti mehanizam $m$. quadricepsa femoris (mišića, ivera i patelarnog ligamenta) s aksijalnom osi uda, osigurati dubinu hrskavičnog žlijeba valjka bedrene kosti, zategnuti meko tkivo s lateralne strane ivera te oslobađanje napetosti mekog tkiva $s$ medijalne strane ivera. Ove čimbenike treba procijeniti i ispraviti u svakog pacijenta koji je podvrgnut kirurškom liječenju medijalnog iščašenja ivera. Postoji više vrsta kirurških tehnika rekonstrukcije mekih tkiva i rekonstrukcije kosti. Odluka koju tehniku koristiti temelji se na nalazu rendgenskih snimki (npr. deformacija kosti) i procjeni tijekom operativnog zahvata (npr. dubina hrskavičnog žlijeba). Lateralna artrotomija provodi se kako bi se dobio uvid u zglob, posebice u stanje prednjih križnih ligamenata, zglobne hrskavice te kaudalni dio ivera. Korištenje tehnika rekonstrukcije mekih tkiva treba se ograničiti na prvi stupanj medijalnog iščašenja ivera, jer se tako ne mogu nadići skeletne deformacije i to je najčešći razlog neuspjeha operativnog zahvata.

Zatezanje lateralnog retinakuluma primjenjuje se kod medijalnog iščašenja ivera dok se medijalno zatezanje retinakuluma primjenjuje kod lateralnog iščašenja. Retinakulum i zglobna kapsula se zarežu tri do pet milimetara od i paralelno $s$ iverom te se rez produži od goljenične kosti proksimalno do točke koja je jedan do dva centimetra iznad ivera. Rezni rub široke fascije pričvršćen za iver zašiven je za lateralni retinakulum s nekoliko madracnih šavova koji prolaze kroz zglobnu kapsulu. Nakon toga površinski dijelovi fascije i kapsule budu zašiveni za široku fasciju koja ostaje pričvršćena na iver. Ova metoda može biti kombinirana sa šavovima za sprječavanje rotacije potkoljenice i ivera.

Medijalna se rotacija potkoljenice može spriječiti neresorptivnim šavom koji prolazi od lateralne fabele do goljenične kvrge ili distalnog dijela patelarnog ligamenta. Ovaj šav često je korišten $\mathrm{u}$ kombinaciji $\mathrm{s}$ trohleoplastikom $\mathrm{u}$ starijih pasa s drugim stupnjem iščašenja ivera, ali se može koristiti i samostalno u štenadi. Ovaj šav u dosta slučajeva 


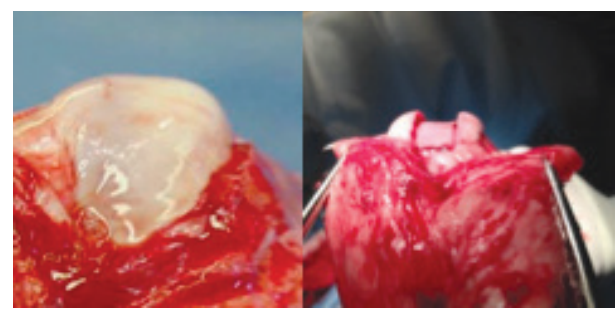

Slika 3. Prikaz istrošenog i ravnog hrskavičnog žlijeba valjka bedrene kosti (slika lijevo) te izgled žlijeba nakon blok trohleoplastike

može puknuti ili se otpustiti, međutim, fibrozno tkivo koje se formira oko šava te usklađen mehanizam $m$. quadricepsa femoris može zadržati novu poziciju ivera ili potkoljenice.

Dezmotomija i parcijalna kapsulektomija rijetko su korištene samostalno, već se češće koriste $\mathrm{u}$ kombinaciji $\mathrm{s}$ drugim metodama. Dezmotomija se odnosi na jednostavno otpuštanje retinakuluma $s$ one strane $u$ koju je iver iščašen. Iver normalno klizi u smjeru proksimalno-distalno paralelno s valjkom bedrene kosti. Kontrakcijom zglobne kapsule dolazi do izlaženja ivera iz valjka bedrene kosti u koso prema onoj strani gdje je povučen retinakulumom. Dezmotomija sprječava takvo kretanje ivera u koso. Rez počinje od goljenične kosti kroz zglobnu kapsulu i retinakulum dovoljno proksimalno kako bi se otpustila sva napetost nad iverom. Ovaj rez se obično ostavlja otvorenim kako ne bi došlo do ponovnog stvaranja napetosti. Šavovi koji povezuju rub ivera s dubokom fascijom spriječit će nestabilnost ivera. Parcijalna kapsulektomija odnosi se na eliptično izrezivanje dijela zglobne kapsule i retinakuluma na stranu suprotnu od strane iščašenja ivera. Šivanjem rubova dobiva se zatezanje zglobne kapsule i stabilnost ivera.

Trohleoplastike su tehnike produbljivanja plitkog, odsutnog ili čak konveksnog hrskavičnog žlijeba bedrenog valjka (Slika 3.). Postoji nekoliko načina, a svaki uključuje ozljedu zglobne hrskavice što se preporučuje izbjegavati, posebice $u$ velikih pasmina pasa. Male pasmine pasa dobro podnose ovu vrstu operativnog zahvata, iako je ponekad povratak potpune funkcije koljena sporiji. Konveksni ili ravni bedreni valjak najčešće se viđa u kombinaciji sa zarotiranim distalnim dijelom bedrene kosti. Ipak, u nekih velikih i gigantskih pasmina pasa potrebno je učiniti osteotomiju kako bi se dobila visina medijalnog grebena i postigla stabilnost ivera.

Trohlearna hondroplastika temelji se na tehnici "hrskavičnog flapa" korisna je u štenaca do deset mjeseci starosti. Što je životinja zrelija, to je hrskavica tanja i jače povezana sa subhondralnom kosti i time je izvođenje "flapa" otežano. Hrskavica iz žlijeba bedrenog valjka se izreže i podigne te se zatim makne dio subhondralne kosti ispod nje. Nakon toga se hrskavica spusti u produbljeni žlijeb. U slučaju da žlijeb nije dovoljno produbljen postupak se može ponoviti. Prednost ove metode je što je žlijeb produbljen, a zadržana je hrskavica.

Klinastom trohleoplastikom postiže produbljivanje hrskavičnog žlijeba tako da se pilom izreže hrskavica u obliku slova V (Slika 4.). Drugim rezom proširuje se i uklanja dio kosti. Zatim se koštani dio zamjenjuje izrezanom hrskavicom i tvori novi produbljeni žlijeb. Blok trohleoplastika, za razliku od prijašnje, se razlikuje $u$ toliko što je hrskavični dio koji se izrezuje paralelnih stjenki, a ne u obliku slova V (Slika 4.).

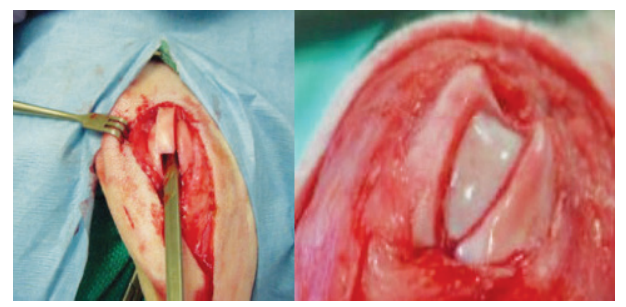

Slika 4. Prikaz hrskavičnog žlijeba nakon blok trohleoplasike (lijevo; Izvor: http://www. ambulatoryveterinarysurgery.com/patella luxation.html, i prikaz klinaste troheloplastike (desno); Izvor: http://www.fitzpatrickreferrals. co.uk/orthopaedic/patellar-luxation/ 
Time se omogućava veće produbljivanje žlijeba proksimalno. Učine se dva paralelna reza kroz hrskavicu i kost duž hrskavičnog žlijeba od vrha bedrenog valjka pa sve do razine hvatišta stražnjih križnih ligamenata. Osteotomom ili pilom se učini rez kojim se povežu dva paralelna reza iznad stražnjih križnih ligamenata. Izrezani blok se izvadi te se uklanja trabekularna kost i zatim se blok ponovno utisne.

Abrazijska trohleoplastika se gotovo više ne koristi. Produbljivanje žlijeba postiže se kiretažom zglobne hrskavice do razine subhondralne kosti, a širina novog žlijeba mora odgovarati širini ivera te biti gladak. To se postiže struganjem koristeći osteotom ili "rašpu". Iako je destruktivna za cijelu hrskavicu žlijeba, ova metoda daje dobre rezultate $u$ malih pasmina pasa.

\section{Transpozicija goljenične kvrge}

Ovom metodom ispravlja se iskrivljena linija patelarnog ligamenta i kretanja ivera u koso. Točno mjesto vezivanja patelarnog ligamenta na goljeničnu kvrgu ustvrđuje se palpacijom. Osteotomija počinje na sredini između kranijalnog dijela platoa tibije i mjesta hvatišta patelarnog ligamenta i proteže se do dis- talnog dijela goljenične kvrge. Osteotomija se izvodi ručnom ili oscilirajućom pilom te se goljenična kvrga premješta lateralno kako bi se uskladio i poravnao ekstenzorni mehanizam. Usklađivanje m. quadricepsa femoris, ivera, patelarnog ligamenta i goljenične kvrge procjenjuje se dok životinja leži u dorzalnom položaju. Bilo bi dobro upotrijebiti neki ravni instrument da bude sigurno da su sve strukture u ravnini. Dvije Kirschnerove igle adekvatne veličine postavljaju se kako bi držale goljeničnu kvrgu u njenoj novoj poziciji (Slika 5.). U velikih i aktivnih pasa, ako je prevelika napetost $\mathrm{i}$ postoji mogućnost nastanka loma, buši se distalno od mjesta osteotomije i provlači se ortopedska žica koja se veže oko Kirschnerovih igli u obliku broja osam i tako smanjuje napetost koju prouzroči kontrakcija m. quadricepsa femoris. Nakon šest do osam tjedana radi se rendgensko snimanje kako bi se dobio uvid u cijeljenje i stabilnost implantanata. Postoji i kirurški instrumentarij specijaliziran za transpoziciju goljenične krvge; engl. tibial tuberosity transposition tool (TTTT) izumitelja Massima Petazzonija (Petazzoni, 2014.) kojim se postupno, pod kontrolom mikro pokreta vijaka vodilice radi transpozicija.
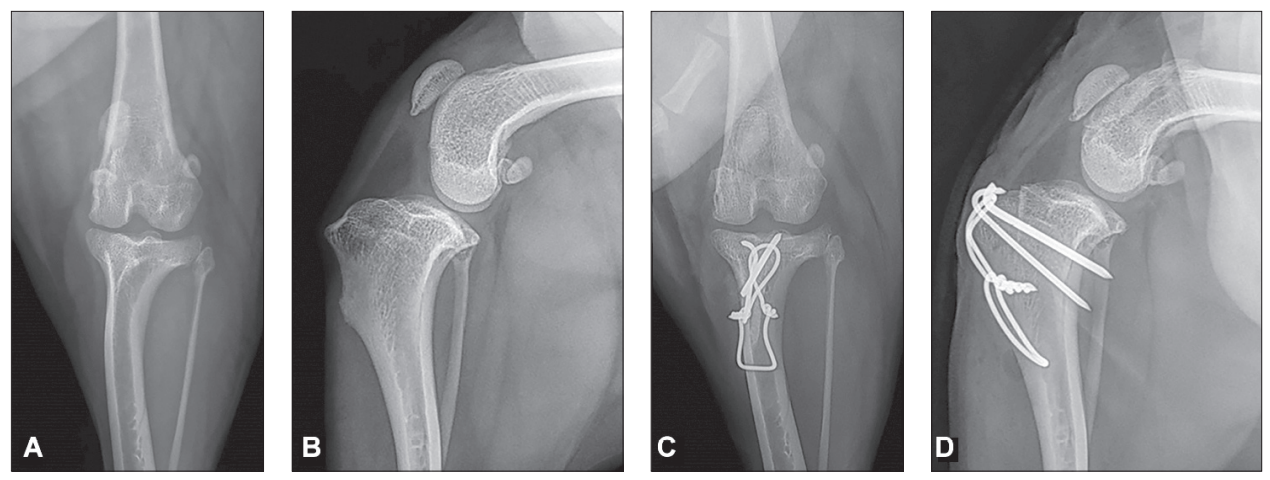

Slika 5. Rendgenski prikaz transpozicije goljenične kvrge. A sagitalna projekcija koljena prije zahvata, B profilna projekcija koljena prije zahvata, C sagitalna projekcije transpozicije goljenične kvrge, D profilna projekcija transpozicije goljenične kvrge. Izvor: https://doi.org/10.2147/VMRR.S142545 


\section{Patelektomija}

Patelektomija se radi u rijetkim slučajevima kada dolazi do ozbiljnih erozija zglobne hrskavice i unatoč ostalim metodama usklađivanja mehanizma m. quadricepsa femoris. Incizija se radi vertikalno po sredini preko ivera te se oštricom skalpela nježno odvoje tetiva $m$. quadricepsa femoris, retinakulum, zglobna kapsula i patelarni ligament od ivera po kvadrantima. Nakon vađenja ivera sve se opet zašije neresorptivnim koncem.

\section{Korektivne osteotomije}

Pri svim korektivnim osteotomijama treba izračunati CORA (center of rotation of angulation), odnosno točno točku (centar) reza korektivne osteotomije za ispravljanje kuta deformacije i kuta rotacije s obzirom na anatomsku i mehaničku osovinu kosti.

Velik naglasak je stavljen na mjerenje oblika bedrene kosti zbog deformacija kao što je distalni varus bedrene kosti

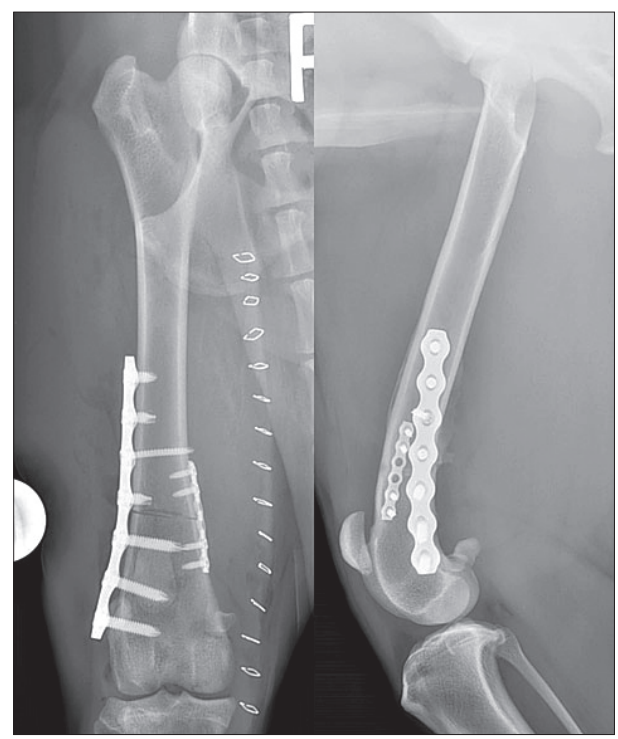

Slika 6. Dvije projekcije bedrene kosti nakon korektivne osteotomije u svrhu liječenja medijalnog iščašenja ivera u psa. Izvor: https:// asgvets.com/medial-patellar-luxation/.
(Swiderski i Palmer, 2007.). On se tretira korektivnom osteotomijom bedrene kosti (CFO) te ujedno ispravlja i medijalno iščašenje ivera. To su suvremene i vrlo komplicirane metode preuzete iz humane medicine. Varus bedrene kosti se određuje mjerenjem kuta varusa bedrene kosti (FVA) ili anatomskog lateralnog distalnog kuta bedrene kosti (aLDFA) (Dudley i sur., 2006.). CFO se preporučuje kada je medijalno iščašenje ivera popraćeno kutom varusa bedrene kosti većim od $12^{\circ}$ (Ikuta i sur., 2008.). Ova mjerenja služe kako bi se moglo točno izračunati koliki se dio kosti mora izrezati kako bi se ispravila deformacija kosti. Izrezani dio kosti je razlika između izmjerenog kuta i željenog postoperativnog kuta. Kada je poznat željeni kut, duljina baze dijela kosti koji se izrezuje određuje se pomoću grafičke metode u kojoj se taj dio ucrta izravno rendgenogram ili se određuje trigonometrijski pomoću promjera bedrene kosti u razini osteotomije. Dugoročno praćenje i procjenjivanje pasa velikih pasmina koji su podvrgnuti korektivnoj osteotomiji bedrene kosti zbog varusa bedrene kosti popraćenog medijalnim iščašenjem ivera, pokazalo je uspješno zacjeljivanje, stabilizaciju ivera i dugoročno ozdravljenje (Swiderski i sur., 2008.). Ukoliko je došlo do deformacije potkoljenice pri čemu transpozicija goljenične kvrge neće ispraviti iščašenje, potrebna je proksimalna osteotomija potkoljenice (PTO) kao izbor liječenja iščašenja. Slika 6. prikazuje korektivnu osteotomiju bedrene kosti.

\section{Zamjena hrskavičnog žlijeba implantatom (PGR) i Ridgestop}

Zamjena oštećenog $\mathrm{i} / \mathrm{ili}$ istrošenog hrskavičnog žlijeba pomoću proteze predstavlja noviju metodu liječenja vrijednu razmatranja. Proteza osigurava nisku razinu trenja, površina je otporna na ogrebotine i može izdržati tlakove 

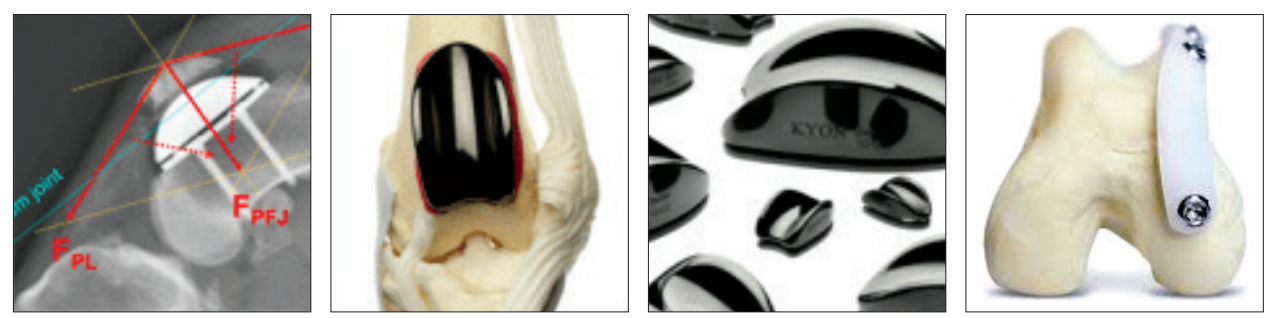

Slika 7. Prikaz proteze PGR i načina njenog djelovanja. Izvor: http://www.kyon.ch/current-products/ patellar-groove-replacement-pgr. Slika skroz desno prikazuje Ridgestop implantat i njegov položaj. Izvor: https://www.orthomed.co.uk/systems/ridgestop-patella-luxation-repair-systems/

i klizno trenje koje prouzroči dodir zglobne plohe i ivera. Proteza se sastoji se od dvije komponente: gornja anatomski oblikovana komponenta žlijeba izrađena je od legure titana, visoko polirana i obrađena $s$ amorfnim dijamantnim slojem (ADLC). Kliničko značenje ove suvremene metode je u tome da se smanji mogućnost nastanka osteoartritisa, poboljša stabilnost ivera i ispravi ekstenzorni mehanizam unutar jednog operativnog zahvata (Dokić i sur., 2015.).

Ridgestop je nova kirurška tehnika za liječenje iščašenja ivera. Jednostavna alternativa trohleoplastici koja se može upotrijebiti sama, kao jedini način liječenja iščašenja, ili $u$ kombinaciji $s$ nekom drugom metodom. Prednosti ove metode su to što je minimalno invazivna, učinkovita i zahvat je ponovljiv. Primjenjuje se poseban implantat zvan RidgeStop ${ }^{\mathrm{TM}}$ koji se pričvrsti pomoću dva do tri vijka na stranu hrskavičnog žlijeba na koju se iver iščaši, stvarajući tako prepreku koja sprječava da se to dogodi. Ova metoda ne oštećuje hrskavicu te je dugoročno rješenje zbog toga što se preko implantata ne prenosi težina kada životinja optereti nogu. Obje opisane tehnike prikazane su na slici 7 . Nedostatak ovih suvremenih tehnika je svakako viša cijena.

\section{Zaključak}

U današnje vrijeme i dalje puno slučajeva medijalnog iščašenja ivera ostaje ne- otkriveno što zbog nerazjašnjenih uzroka, diskretnih kliničkih znakova ili neupućenosti vlasnika. Važno je pri rutinskom pregledu s obzirom na pasminsku predispoziciju pridati pozornost iščašenju ivera te upoznati vlasnike s ovim problemom. Potrebno je reagirati već u mladoj dobi životinje zbog mogućih deformacija kostiju, ali i pri nižem stupnju iščašenja. Zahvat je potrebno isplanirati te $u$ skladu s tim odabrati metodu koja će se koristiti. Bitno je odabrati metodu ili kombinaciju metoda kako bi se ispravilo iščašenje, ali ujedno i mogućnost komplikacija svela na najmanju moguću mjeru, a životinja što bezbolnije i brže oporavila te vratila funkciju uda.

\section{Literatura}

1. CAMPBELL, C. A., C. L. HORSTMAN, D. R. MASON and R. B. EVANS (2010): Severity of patellar luxation and frequency of concomitant cranial cruciate ligament rupture in dogs: 162 cases (2004-2007). J. Am. Vet. Med. Assoc. 236, 887.

2. DENNY, H. R. and S. J. BUTTERWORTH (2000): A Guide to Canine and Feline Orthopedic Surgery, Oxford, Blackwell Sci., pp. 517-525.

3. DUDLEY, R. M., M. P.KOWALESKI and W. T.DROST (2006): Radiographic and computed tomographic determination of femoral varus and torsion in the dog. Vet. Radiol. Ultrasound 47, 546-552.

4. DOKIĆ, Z., D. LORINSON, J. P. WEIGEL and A. VEZZONI (2015): Patellar groove replacement in patellar luxation with severe femoro-patellar osteoarthritis. Vet. Comp. Orthop. Traumatol. 28, 124-130.

5. GALLEGOS, J., M. UNIS, J. K. ROUSH and L. AGULIAN (2016): Postoperative Complications and Short-Term Outcome Following Single-Session Bilateral Corrective Surgery for Medial Patellar 
Luxation in Dogs Weighing < 15 kg: 50 Cases (20092014.) Vet. Surg. 45, 887-892.

6. IKUTA, C. L., R. H. PALMER and J. M. CADMUS (2008): Does radiography permit accurate measurement of femoral angulation across a range of femoral conformations? Proceedings of the $35^{\text {th }}$ Annual Conference of Veterinary Orthopedic Society Big Sky, Montana (USA), p. 29.

7. L'EPLATTENIER, H. and P. MONTAVON (2002): Patellar luxation in dogs and cats: Pathogenesis and diagnosis. Compend. Contin. Educ. Pract. Vet. 24, 234-239.

8. PETAZZONI, M. (2014): Tibial Tuberosity Transposition Tool. A novel surgical technique for TTT. Congress Proceedings. 17 ESVOT Congress, Venice, Italy.
9. REZENDE, C. M. F., C. S. TÔRRES, A. C. NEPOMUCENO, J. S. LARA and J. A. C. VARÓN (2016): Patellar Luxation in Small Animals. Canine Medicine - Recent Topics and Advanced Research. InTech. 159-178.

10. ROUSH, J. K. (1993): Canine patellar luxation. Vet. Clin. North Am. Small Anim. Pract. 23, 855-868.

11. SWIDERSKI, J. K. and R. H. PALMER (2007): Longterm outcome of distal femoral osteotomy for treatment of combined distal femoral varus and medial patellar luxation: 12 cases (1999-2004). J. Am. Vet. Med. Assoc. 231, 1070-1075.

12. SWIDERSKI, J. K., S. V. RADECKI and R. D. PARK (2008): Comparison of radiographic and anatomic femoral varus angle measurements in normal dogs. Vet. Surg. 37, 43-48.

\section{Diagnostic and surgical treatment of medial patellar luxation in dogs}

Marko PEĆIN, DVM, PhD, Assistant Professor, Faculty of Veterinary Medicine University of Zagreb, Croatia; Anja SAMARDŽIĆ, DVM, Croatia; Ozren SMOLEC, DVM, PhD, Associate Professor, Mario KRESZINGER, DVM, PhD, Full Professor, Faculty of Veterinary Medicine University of Zagreb, Croatia

Medial patellar luxation is a common occurrence and the cause of lameness in small dog breeds, and therefore of great significance in veterinary practice. However, surgical treatment of light cases, such as grade I is often avoided and not considered essential. In most cases, conservative treatment is insufficient. Luxations can occure due to trauma or can be present at birth, which is often associated with more severe bone deformations. It is hereditary disease. The severity of clinical signs depends on the degree of patellar luxation, though there may be no clinical signs until diagnosis is made during routine clinical examination. Apart from an orthopaedic examination, the diagnosis is set after radiography which can be negative in grade I or even grade II. The type of surgery depends on the degree of luxation and may be based on soft tissue or bone reconstruction. The most commonly used techniques are overlap of the lateral retinaculum, medial retinaculum release, trochleoplasty and transposition of tibial tuberosity laterally or distally. In severe bone deformations, osteotomy of the femur is applied. There are now modern methods to treat this orthopaedic problem, such as the use of endoprosthetic implants that enhance or substitute the patellar grove completely. An important role in treatment should be given to postoperative analgesia and leg immobilization. There are fewer complications, though there may be a recurrence of patellar luxation and loosening of implants, as the most common complication, or tibial crest fractures as the most severe complication. In most cases, the prognosis is excellent, the leg returns to normal function and lameness does not appear. This paper describes the clinical signs, diagnostic procedures and surgical treatment of medial patellar luxation in dogs with several of the mentioned modern techniques.

Key words: patella; luxation; degree of luxation; surgical treatment; implants 